臨床ノート

\title{
甲状腺の手術適応と手術法
}

\section{Indications for Thyroid Surgery and Operative Techniques}

小池 靖 夫

甲状腺手術には，耳鼻咽喉科領域の他の手術 とは質的に異なる面があるので，手術に際して は，乙うした特異性に充分注意した取り扱いが 要求される。 しか屯最近，甲状腺疾患に対する 治療技術が急速に進歩し，甲状腺手術に対する 考え方に屯従来とはかなりの違いがみられるよ うになった。

そこで今回の臨床ノートでは，乙の分野の第
一線で活躍中の熟練家諸氏に，甲状腺手術に関 する最近の考え方や，技術の要点を披露して頂 くこととした．従来の手術書には書かれていな いコッが，各項目でとに数多く記載されている. 耳鼻咽喉科の臨床における甲状腺診療のウエイ 卜が次第に大きくなりつつある今日，多数の耳 鼻科医が甲状腺手術に対する興味と関心を深め て下さるととを希望する.

\section{1. 手術適応の判断と術式の選択}

\section{小 池 靖 夫}

\section{手術適応について}

甲状腺疾患に対して手術的治療を行うべきか 否かの判断は，検查成績が充分に揃っていたと してあ，必ずしも容易ではない。乙れは，甲状 腺手術の特異性に由来するあのであって, 最終 的にはいくつかの条件を考元合わせ，総合的な 見地汃ら判断するほかない場合も多い，従って， 甲状腺手術の適応をきめるための絶対的基準を 作ることは困難であり, case by case に手術適応 の存否が判断されるべきである.

手術適応の判断に際して第一に考慮すべきて
とは，甲状腺が内分泌腺の一つである事実であ ろう. 甲状腺は単に甲状腺ホルモンを分泌して 代謝を調節しているばかりでなく，他の内分泌 腺乙も密接に関連して，機能的な均衡状態を保 っている．従って甲状腺に対して手術的操作を 加えることは，乙の機能的均衡を変化させるこ とを意味するのである. 甲状腺組織を多少切除 したところで，血中サイロキシン濃度が変化し ないのは事実であるが，それは決して生体に影 響がなかったわけではなく，異った均衡状態が もたらされたのである。例えば TSH 值の水準 
は術前とは異なる。

なお甲状腺機能艺進症に対しては, 抗甲状腺 剂やアイソトープ治療などの治療手段もあるか ら, 各種治療法の利害得失を検討した上で手術 の適応とするか否かが判断される，乙の点は項 目 3 ，で詳述されている，ただ，甲状腺機能立 進症が主として内科医によって治療されている ため，実際には明らかに手術適応であるあので あ, 長期間薬物治療の対象とされているものが 少なくない，患者中心の医療という立場から考 えるならば，本症は手術者をあ含めた診療チー ムによって扱われるのが妥当であろう.

手術適応に関して考慮すべき第二点は，手術 創の問題である. 甲状腺が前頸部に位置するた め, 術後の瘢痕が外から見えることは避け難い. とくに若年の女子にとっては，乙れはかなりの 心理的負担になる. 従って患者の性別, 年齢や, 未婚か否かなどの社会的条件屯，悪性腫瘍以外 の甲状腺疾患に対する手術適応を判断する場合 には，充分に考慮すべきである，患者自身とば かりでなく，親や配偶者など，患者の周囲の人 人とも話し合いをすべきであろう.

一方，術創を目立たなくするための努力も勿 論必要である，術後に梯子状の洀痕を来すよう な縫合法は論外である。減張縫合や埋没縫合を 利用して切創に加わる緊張を最小限とし，さら に術創を圧迫するなど，形成外科的手技を採用 するととによって頸部痽痕を目立たなくするて とが望まれる，乙のような瘢痕対策を実行し得 る施設では，甲状腺手術の適応の幅がその分だ け広いというべきであろう。

手術適応に関して考慮すべき第三点は，副損 傷の予防である。解剖学的位置関係から，甲状 腺手術に際しては上下喉頭神経や上皮小体の機 能障害を来し易い。項目 2 . で詳述されている ように，乙れらの副損傷を避けるために最大限 の注意をはらうことは甲状腺手術者の義務であ る.しかしそれであなお，副損傷のリスクは 0 ではない，従ってとくに良性の甲状腺疾患に対 する手術適応を考えるときには，乙のリスクを
念頭におき，慎重な術式選択を行うべきであろ う. とくに術後の上皮小体機能不全は，一般に 信じられているよりあ実際にははるかに多いの である。

\section{術式の選択について}

甲状腺手術の術式としては, 部分切除, 葉切 除，亜全剔，全剔といった区分が一般に行われ ている.しかし臨床的には，もう少し細かな区 分を考えるほうが便利である。

a. 甲状腺部分切除

この術式はさらに, 核出 enucleation, 峡切除 isthmus resection, 葉部分切除 partial lobectomy, 葉西全剔 subtotal lobectomy に細分するこ とができる、核出は，境界明瞭な腫瘤を，腫瘤 の表面に密着して剔出する手技であり, 項目 4 . に詳細な記載がある. 峡切除は甲状腺峡を錐体 葉とともに切除する術式であって, 主として喉 頭，気管に対する機械的圧迫を軽減させる目的 で行われる ${ }^{12}$. 橋本病による音声障害や，咽喉 頭異常感に対する治療法としても有効である2 残った腺葉の断端は縫合閉鎖する.

葉部分切除は小さな良性腫瘍の場合に用いら れる方法で, 腫瘍周囲に健常甲状腺組織をつけ たまま切除する。断端は被膜で覆われるよう， 縫い縮める. 葉亜全剔は葉部分切除の範囲をひ ろげたもので, 上甲状腺動静脈を切断し, 腺葉 の大部分を切除するが，葉被膜の背側端だけは 残存させる. この方法をとると下喉頭神経なら びに上皮小体に対する侵襲を最小にとどめるこ とができるので, 良性腫瘍で, 病変が甲状腺後 端に及んでいないときに選択される。なお，筆 者らは術中に迅速組織診を行い，手術所見とあ わせて最終的な術式をきめている.

b. 甲状腺葉切除

一側腺葉の切除であって, 項目 4 . 亿詳細な記 述がある，悪性腫瘍の場合には少なくとも一側 の葉切除を行うのが普通である。ただし，一側 の葉切除だけであ上皮小体機能不全をおこすと とがあるから，上皮小体を可能な限り温存する 努力を意ってはならない. 


\section{c. 甲状腺亜全剔}

甲状腺機能六進症に対しては，葉西全剔を両 葉に行うのが普通である. 項目 3 . 亿詳細な記載 がある. 悪性腫瘍に対しては, 一側の葉切除之 他側の葉西全剔とを組み合わせて甲状腺亚全剔 とすることが多い．乙の場合は甲状腺機能を残 すととよりも，下喉頭神経や上皮小体に対する 侵襲を小さくすることに重点がある，従って例 えば上皮小体に血行障害が生じてしまったとき には，乙れを近くの筋組織内に移植する等の配 慮が必要である。

d. 甲状腺全剔

悪性腫瘍の場合に選択される. 両側の葉切除 である，上下喉頭神経は，癒着がない限り温存 すべきである，多くの場合，上皮小体機能を保 全するととが難しくなるから，上皮小体を探し 出して筋組織内に移植する等の対策が必要とな る.上皮小体を見分けることは，馴れればそう 難しいことではないが，その一部を迅速組織診 にまわして確認しておくことが望ましい。

\section{e. 頸部郭清}

悪性腫瘍については, 頸部郭清を行うべきか 否か，また行うならばその範囲が問題となる. 項目5.に詳しい discussion がある、筆者らは, 濾胞癌の場合, 甲状腺全剔と傍気管リンパ節郭 清にとどめている，乳頭癌の場合には進展度に 応じて郭清を行うが，内頸静脈ならびに胸鎖乳 突筋は原則として切除しない. しかし扁平上皮 癌や䯣様癌では，根治的な頸部郭清を行う。甲 状腺悪性腫瘍では，乙のように，腫瘍の性格に 応じて術式を選択することがきわめて重要だと 思われる.

\section{文献}

1) Lahey $\mathrm{FH}:$ Excision of the thyroid isthmus for relief of pressure. Surg Gynecol Obstet 48 : 498 500, 1928.

2) Koike Y, et al : Laryngeal Complaints and Voice Disorders Due to Goiter and Their Operative Treatment. Record of 11th International Congress of Broncho-esophagology. pp 16 20, Hakone, 1965.

\title{
2. 上下喉頭神経と上皮小体の処理
}

\author{
太田文彦
}

甲状腺手術は頭頸部外科の大きな部分を占め ているにも拘らず，以前はどういうわけか耳鼻 咽喉科医が避けて通っていたような傾向がある. 最近は耳鼻咽喉科の学会にも甲状腺の演題が増 えつつあるが, 甲状腺外科検討会や内分泌外科 学会への耳鼻咽喉科医の参加はまだまだ少ない. そういった意味でこの臨床ノートが企画された ことは意義がある。

\section{上下喉頭神経の処理}

甲状腺手術のなかで筆者が耳鼻咽喉科医とし て強い関心を抱いてきたのは，上下喉頭神経の
処理である。上喉頭神経は主として喉頭の知覚 枝として，下喉頭神経は運動枝としてわれわれ 耳鼻咽喉科医にとって深い関わりを有する神経 である。いわゆる甲状腺外科医といわれる専門 家のなかにすら，てれらの神経を犠牲にするて とに対してそれ程重大なとととは考えていない のではないかと思われることすらある。乙れに 対して耳鼻咽喉科医は喉頭の機能について関心 をもち，乙れらに神経を損傷した後の障害の意 味するところを熟知しているので，乙れらの神 経に対していささか神経質とも思われる手術を 